\title{
Relating the hygroscopic properties of submicron aerosol to both gas- and particle-phase chemical composition in a boreal forest environment
}

\author{
J. Hong ${ }^{1}$, J. Kim ${ }^{2}$, T. Nieminen ${ }^{1,3}$, J. Duplissy ${ }^{1}$, M. Ehn ${ }^{1}$, M. Äijälä ${ }^{1}$, L. Q. Hao ${ }^{2}$, W. Nie ${ }^{1,4}$, N. Sarnela ${ }^{1}$, N. L. Prisle ${ }^{1}$, \\ M. Kulmala ${ }^{1}$, A. Virtanen ${ }^{2}$, T. Petäjä ${ }^{1}$, and V.-M. Kerminen ${ }^{1}$ \\ ${ }^{1}$ Department of Physics, University of Helsinki, P.O. Box 64, 00014 Helsinki, Finland \\ ${ }^{2}$ Department of Applied Physics, University of Eastern Finland, 70211 Kuopio, Finland \\ ${ }^{3}$ Helsinki Institute of Physics, University of Helsinki, P.O. Box 64, 00014 Helsinki, Finland \\ ${ }^{4}$ Institute for Climate and Global Change Research \& School of Atmospheric Sciences, \\ Nanjing University, Nanjing, 210093, China
}

Correspondence to: J. Hong (juan.hong @ helsinki.fi)

Received: 12 May 2015 - Published in Atmos. Chem. Phys. Discuss.: 9 June 2015

Revised: 1 October 2015 - Accepted: 18 October 2015 - Published: 28 October 2015

\begin{abstract}
Measurements of the hygroscopicity of 15$145 \mathrm{~nm}$ particles in a boreal forest environment were conducted using two Hygroscopicity Tandem Differential Mobility Analyzer (HTDMA) systems during the Pan-European Gas-Aerosols-climate interaction Study (PEGASOS) campaign in spring 2013. Measurements of the chemical composition of non-size segregated particles were also performed using a high-resolution aerosol mass spectrometer (HR-AMS) in parallel with hygroscopicity measurements. On average, the hygroscopic growth factor (HGF) of particles was observed to increase from the morning until afternoon. In case of accumulation mode particles, the main reasons for this behavior were increases in the ratio of sulfate to organic matter and oxidation level $(\mathrm{O}: \mathrm{C}$ ratio) of the organic matter in the particle phase. Using an $\mathrm{O}: \mathrm{C}$ dependent hygroscopic growth factor of organic matter $\left(\mathrm{HGF}_{\mathrm{org}}\right)$, fitted using the inverse Zdanovskii-Stokes-Robinson (ZSR) mixing rule, clearly improved the agreement between measured HGF and that predicted based on HR-AMS composition data. Besides organic oxidation level, the influence of inorganic species was tested when using the ZSR mixing rule to estimate the hygroscopic growth factor of organics in the aerosols. While accumulation and Aitken mode particles were predicted fairly well by the bulk aerosol composition data, the hygroscopicity of nucleation mode particles showed little correlation. However, we observed them to be more sensitive to the gas phase concentration of condensable vapors:
\end{abstract}

the more sulfuric acid in the gas phase, the more hygroscopic the nucleation mode particles were. No clear dependence was found between the extremely low-volatility organics concentration (ELVOC) and the HGF of particles of any size.

\section{Introduction}

Atmospheric aerosols can influence Earth's climate both directly and indirectly through affecting the radiation balance, or altering the albedo, lifetime and precipitation patterns of clouds (Stevens and Feingold, 2009; IPCC, 2013; Regayre et al., 2014; Rosenfeld et al., 2014). However, inadequate characterization of the spatial and temporal variability of the aerosol size distribution, chemical composition and hygroscopic properties make it very difficult to quantify the aerosol climatic effects. In terms of aerosol chemical composition, the biggest challenges are due to the presence of a vast number of different organic components in aerosol particles, the physical-chemical properties of which vary largely in the atmosphere (e.g., Jimenez et al., 2009).

Laboratory experiments studying hygroscopic properties of secondary organic aerosols (SOAs) have been performed intensively around the world. Meyer et al. (2009) studied the hygroscopicity of ammonium sulfate seeded and unseeded SOA derived from photo-oxidation of $\alpha$-pinene and found an 
increase in the hygroscopic growth factor (HGF) when the SOA volume fraction was increased, indicating an increased dissolution of inorganic species or a negative solute-solute interaction at $75 \%$ RH. Varutbangkul et al. (2006) studied the hygroscopic properties of SOA produced by the oxidation of various organic precursors in a smog chamber. They found that the HGF of SOA behaved differently with time for different SOA. Duplissy et al. (2011) found that the hygroscopicity of SOA formed in a smog chamber correlated strongly with the relative abundance of oxygenated species, as measured by the oxidation level $(\mathrm{O}: \mathrm{C})$ of organic aerosol in the chamber. More recently, Massoli et al. (2010) and Pajunoja et al. (2015) showed a clear correlation between the oxidation level of SOA and hygroscopicity. According to Pajunoja et al. (2015), the effect of $\mathrm{O}: \mathrm{C}$ on hygroscopicity was pronounced especially at sub-saturated conditions.

Boreal forests emit large amounts of volatile organic compounds (VOCs; for example monoterpenes). In the atmosphere, VOCs are oxidized rapidly and produce, for example, extremely low-volatility organic compounds (ELVOCs; Ehn et al., 2014) that can take part in new-particle formation and the subsequent growth to form SOA. These low-volatility organic compounds constitute more than $50 \%$ of the SOA mass in the boreal environment (Jimenez et al., 2009). However, the physical-chemical properties of these low-volatility organics, especially ELVOCs, are relatively poorly known in this environment due to the diverse properties of these compounds and their temporal variability (Hämeri et al., 2001; Ehn et al., 2007; Raatikainen et al., 2010; Hong et al., 2014).

Measurements of the hygroscopicity of newly formed particles are critical to obtain information on the chemical species involved in the particle formation. This is because the direct determination of the chemical composition of those newly formed particles or nucleation mode particles under field conditions is still challenging, as only a small amount of mass is attributed to the newly formed particles (Ristovski et al., 2010; Wu et al., 2013). Recent studies have been looking at the connection between new particle formation and low-volatility organic species in the atmosphere (Paasonen et al., 2010; Kulmala et al., 2013; Nieminen et al., 2014). Ehn et al. (2014) reported that a significant contribution to the growth of newly formed $3-25 \mathrm{~nm}$ particles could be attributed to these ELVOCs. Hence, by examining the hygroscopic growth factor of nucleation and Aitken mode particles, we can also potentially get a better insight into the water affinity of these extremely low-volatility organics, assumed to be non-hygroscopic or less hygroscopic than many inorganics.

In this study, we carried out measurements of the hygroscopicity of nucleation, Aitken and accumulation mode particles at a boreal forest site in Hyytiälä, located in southern Finland. The main goal of this work is to find out how the hygroscopic properties of ambient submicron aerosols are connected to the aerosol chemical composition and concentration of condensable vapors in the gas phase in this envi- ronment. In order to address this issue, we will (1) investigate the diurnal pattern of the hygroscopicity of differentsized sub-micron particles, (2) carry out a closure study between the Hygroscopicity Tandem Differential Mobility Analyzer (HTDMA)-measured hygroscopic growth factor and the high-resolution aerosol mass spectrometer (HR-AMS)derived hygroscopic growth factor and (3) study the influence of condensable vapors, including $\mathrm{H}_{2} \mathrm{SO}_{4}$ and ELVOCs, on particles hygroscopicity.

\section{Materials and methodology}

\subsection{Measurements}

The measurements were carried out between 6 April and 3 June 2013 as part of the PEGASOS campaign at SMEAR II (Station for Measuring Ecosystem-Atmosphere Relations II) located in Hyytiälä, southern Finland (Hari and Kulmala, 2005). The site is surrounded by a 53-year-old pine forest.

Hygroscopic properties of aerosol particles were measured using a nano-Hygroscopicity Tandem Differential Mobility Analyzer (nHTDMA) and a HTDMA that is part of a Volatility-Hygroscopicity Tandem Differential Mobility Analyzer (VH-TDMA) system. A detailed description of the nHTDMA and VH-TDMA systems and their background principle can be found in Keskinen et al. (2013) and Hong et al. (2014). Briefly, particles of six dry mobility diameters $(15,20,30,60,100$ and $145 \mathrm{~nm} ; \mathrm{RH}<10 \%)$ were selected by a nano DMA (TSI 3085) for 15 and $20 \mathrm{~nm}$ particles and a Hauke-type Differential Mobility Analyzer (DMA; Winklmayr et al., 1991) for 30-145 nm particles then the aerosol flow went through a humidifier with a controlled RH, where they were taking up water and growing in size. Then the aerosols were introduced into a second DMA and a condensation particle counter (CPC, TSI 3010 and TSI 3772), where the growth factor distribution was measured. The relative humidity in the sheath flow of the second DMA was kept at $90 \%$ with an accuracy of $\pm 2 \%$.

The hygroscopicity of particles is often described using a hygroscopic growth factor (HGF) as

$\mathrm{HGF}=\frac{D_{\mathrm{p}}}{D_{0}}$,

where $D_{\mathrm{p}}$ is the particle mobility diameter after humidification to $90 \% \mathrm{RH}$, and $D_{0}$ is the mobility diameter measured under dry conditions $(\mathrm{RH}<15 \%)$.

The number size distribution of 3-1000 nm particles has been measured continuously at the SMEAR II station in Hyytiälä using a twin Differential Mobility Particle Sizer (DMPS) since January 1996 (Aalto et al., 2001). The nonrefractory chemical composition and $\mathrm{O}: \mathrm{C}$ of submicron aerosols were measured using a high-resolution aerosol mass spectrometer (HR-AMS, Aerodyne Research Inc., Billerica, USA). A collection efficiency correction of 0.25 was ap- 
plied to the HR-AMS. Detailed descriptions of the instrument, measurement and data processing can be found in other publications (DeCarlo et al., 2006; Canagaratna et al., 2007). The $\mathrm{O}: \mathrm{C}$ ratio was calculated from the relative mass concentrations of $\mathrm{C}$ and $\mathrm{O}$ in the whole ion fragments across the organic mass spectrum. This is known as the "Aiken-Ambient" method (Aiken et al., 2007). In addition, an "ImprovedAmbient" method (Canagaratna et al., 2015), which provides a more accurate and precise measure of $\mathrm{O}: \mathrm{C}$ ratio than the commonly used "Aiken-Ambient" method, is briefly discussed in the result part. Sulfuric acid and ELVOC concentrations were measured with a chemical ionization atmospheric pressure interface time-of-flight mass spectrometer (CI-APi-TOF, Jokinen et al., 2012) that used nitrate as reagent ion. The sulfuric acid concentration was calculated from the $\mathrm{HSO}_{4}^{-}$and $\left(\mathrm{HNO}_{3}\right) \mathrm{HSO}_{4}^{-}$signals. All ELVOCs were detected as clusters with the nitrate ion, and the total ELVOC concentration was calculated by summing up all the detected organic compounds in a mass range 260-622 Th. In order to get the concentrations of ELVOCs or sulfuric acid, the signals were divided by the reagent ion signals and multiplied by the calibration constant. The instrument was calibrated with a calibration setup described in Kürten et al. (2012).

Concentrations of trace gases (e.g., $\mathrm{SO}_{2}, \mathrm{O}_{3}$ ) and meteorological conditions (temperature and solar radiation in UVB wavelengths) were also measured at the Hyytiälä station. Additional information regarding these instruments can be found in Aalto et al. (2001) and in Hari and Kulmala (2005). The data for these parameters were arithmetically averaged to a $30 \mathrm{~min}$ time resolution. All instrumentation and measured parameters used in this study are summarized in Table 1 .

\subsection{Particle composition data analysis}

Atmospheric particles consist of a large number of different organics and inorganic compounds with different water affinities (Swietlicki et al., 2008). By applying the Zdanovskii-Stokes-Robinson (ZSR) relation (Zdanovskii, 1948; Stokes and Robinson, 1966), i.e., assuming volume additivity, the hygroscopic growth factor of such a mixture can be estimated from the growth factor of each component of the particles and their individual volume fraction by obtaining their respective dry densities and mass fraction from HR-AMS data (Gysel et al., 2007; Meyer et al., 2009).

$\mathrm{GF}_{\mathrm{m}}=\left(\sum_{i} \varepsilon_{i} \times \mathrm{GF}_{i}^{3}\right)^{1 / 3}$.

Here, $\varepsilon_{i}$ is the volume fraction of component $i, \mathrm{GF}_{i}$ is the respective growth factor of $i$, and $\mathrm{GF}_{\mathrm{m}}$ is the growth factor for the mixture. The properties of the compounds that are present in the particles are summarized in Table 2. Saathoff et al. (2003) and Varutbangkul et al. (2006) obtained the growth factor of around 1.11 at the RH of $85 \%$ for the secondary organic aerosol (SOA) formed by photo-oxidation of monoterpene and for oxygenated terpene SOA, which corresponds to the growth factor of about 1.17 at the RH of $90 \%$. Hence, an ensemble mean growth factor of the organics $\left(\mathrm{GF}_{\mathrm{org}}\right)$ as 1.17 was chosen for organic compounds to initialize the comparison between HTDMA measured HGF and HR-AMS derived HGF based on the ZSR mixing rule.

\section{Results and discussion}

\subsection{Overview of measurements}

The temporal evolution of particle number size distribution from DMPS, mass concentrations and mass fractions of chemical species (sulfate, nitrate, ammonium and organics) in submicron particles from the HR-AMS and the hygroscopic growth factor probability density function (GF-PDF) for particles of dry sizes 15,20,30,60, 100 and $145 \mathrm{~nm}$ during the measurement period are plotted in Fig. 1. Based on DMPS data (Fig. 1a) and the classification method introduced by Dal Maso et al. (2005), 22 days were classified as new particle formation events (10 days during April and 12 days during May) and 15 days as non-event.

On average, the water uptake of particles of all sizes (Fig. 1d-i) was higher and more variable before the middle of May, when the new particle formation (NPF) events were observed to take place more frequently, than later in the spring, especially for nucleation $(15,20 \mathrm{~nm})$ and Aitken $(30,60 \mathrm{~nm})$ mode particles. The hygroscopic growth factors of nucleation and Aitken mode particles tended to change on a daily basis. These particles are smaller than accumulation $(100,145 \mathrm{~nm})$ mode particles and generally younger. Hence, the chemical composition of nucleation and Aitken mode particles is expected to be affected more easily or rapidly by condensing vapor concentrations. The general pattern of the observed values of HGF was confirmed by the HR-AMS results, as the aerosol chemical composition (Fig. 1c) varied more before the middle of May and became more stable afterwards. This would imply that organics, which were observed to dominate the aerosol composition after the middle of May (Fig. 1b and c) were the major reason for the lower values of HGF at the end of the measurement period.

In terms of their hygroscopic behavior, nucleation and Aitken mode particles $(15,20,30,60 \mathrm{~nm})$ were mostly internally mixed, whereas an external mixture was observed for accumulation mode particles $(100,145 \mathrm{~nm})$ occasionally. However, such an external mixing was much less frequent and less pronounced (less than $10 \%$ of all measured data) compared with internal mixing, so it will not be taken into account of the overall analysis of the results. 
Table 1. List of instrumentation and measured parameters that were used in this study.

\begin{tabular}{ll}
\hline Instruments & Measured parameters \\
\hline nano-HTDMA & Hygroscopic growth factor (HGF) of 15, 20 nm particles \\
HTDMA & Hygroscopic growth factor (HGF) of 30, 60, 100, 145 nm particles \\
DMPS & Particle size distribution 3-3000 nm \\
High-resolution aerosol mass spectrometer (HR-AMS) & Chemical composition of non-refractory material and O : C of \\
& submicron particles \\
Chemical ionization atmospheric pressure interface & Sulfuric acid and extremely low-volatility organic compounds \\
time-of-flight mass spectrometer (CI-APi-TOF) & concentration in gas phase \\
TEI 43 CTL fluorescence analyzer & $\mathrm{SO}_{2}$ \\
TEI 49C UV-light absorption analyzer (Thermo Fisher & $\mathrm{O}_{3}$ \\
Scientific, Waltham, MA, USA) & \\
Pyranometers & $\mathrm{Solar}^{2}$
\end{tabular}
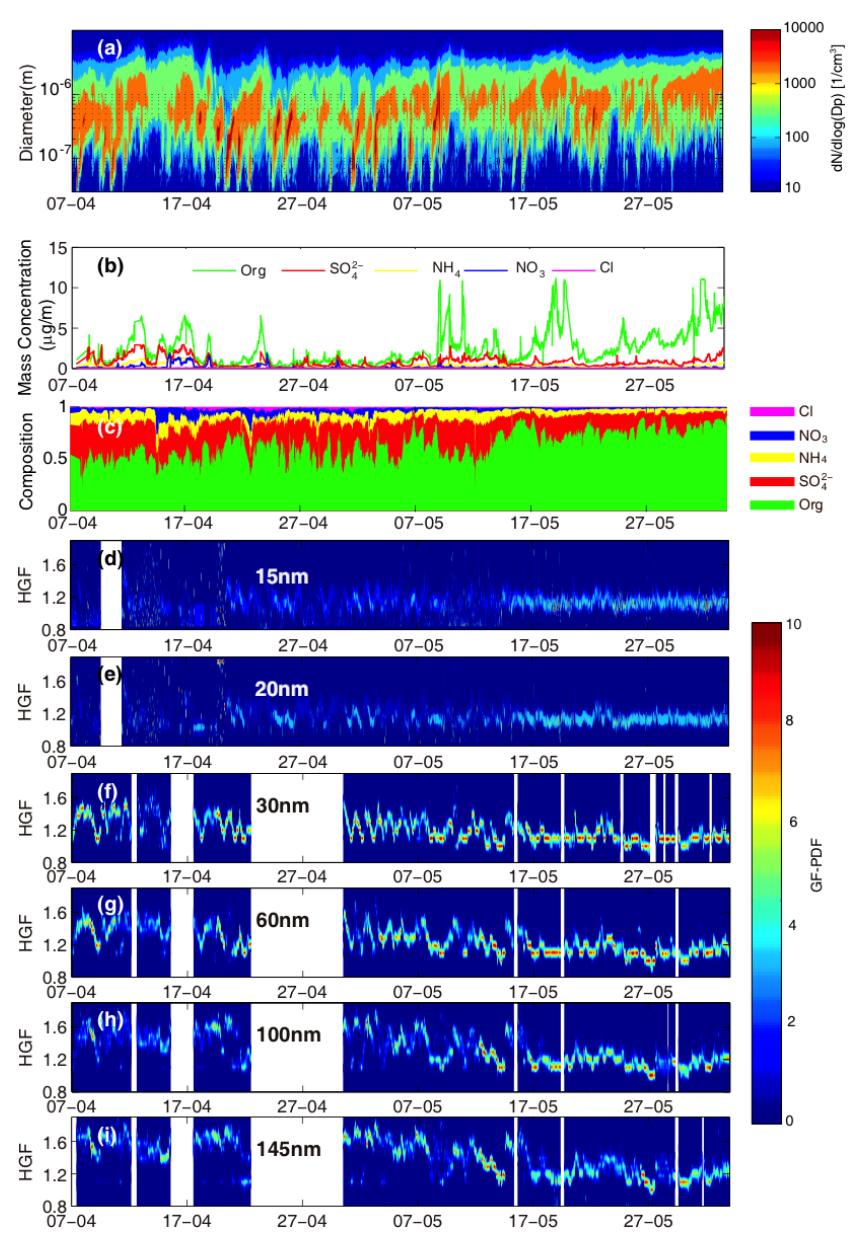

Figure 1. (a) Time series of particle number size distribution using DMPS. (b-c) Time series of mass concentrations and mass fractions of chemical species (sulfate, nitrate, ammonium and organics) in submicron particles from HR-AMS. (d-i) Time evolution of hygroscopic growth factor distribution for 15, 20, 30, 60, 100 and $145 \mathrm{~nm}$ particles using HTDMA.
Table 2. HGF and bulk mass densities of all compounds used in the ZSR calculation (Gysel et al., 2007).

\begin{tabular}{lrr}
\hline & $\begin{array}{r}\text { Density } \\
\left(\mathrm{kg} \mathrm{m}^{-3}\right)\end{array}$ & $\begin{array}{r}\mathrm{GF} \\
(90 \%)\end{array}$ \\
\hline$\left(\mathrm{NH}_{4}\right)_{2} \mathrm{SO}_{4}$ & 1769 & 1.73 \\
$\mathrm{NH}_{4} \mathrm{HSO}_{4}$ & 1780 & 1.81 \\
$\mathrm{NH}_{4} \mathrm{NO}_{3}$ & 1720 & 1.83 \\
$\mathrm{H}_{2} \mathrm{SO}_{4}$ & 1830 & 2.07 \\
Organics & 1400 & $1.17^{*}$ \\
\hline
\end{tabular}

* Growth factor of organic was chosen to be

1.17 according to Varutbangkul et al. (2006).

\subsection{Diurnal behavior}

The diel variation of the hygroscopic growth factor of 15 , 20,30,60, 100 and $145 \mathrm{~nm}$ particles during the measurement period is shown in Fig. 2. Larger particles had, on average, larger values of HGF, which is similar to our earlier findings at the same site (Ehn et al., 2007; Hong et al., 2014) as well as observations in several other sites as well (Asmi et al., 2010; Good et al., 2010; Jung et al., 2014). In general, the HGF of particles of all sizes increased during the morning. For 15 and $20 \mathrm{~nm}$ particles, the HGF reached its maximum $(\sim 1.2)$ around noon. The high values of HGF lasted for several hours for these particles, whereas for larger particles the HGF reached the highest values in the afternoon and then declined until the minimum was reached during nighttime. The HGF of Aitken and accumulation mode particles increased more from morning to afternoon compared with nucleation mode particles, which was likely because of the Kelvin effect. If the Kelvin effect is taken into account, the increase in the HGF of 15 and $20 \mathrm{~nm}$ particles was comparable with that of $100 \mathrm{~nm}$ sized particles. A similar behavior has also been observed in previous studies at our site (Ehn et al., 2007, Hämeri et al., 2001).

The diel variation of the HGF was likely to be affected by both gas-phase chemistry (indirectly) and gas-to-particle 

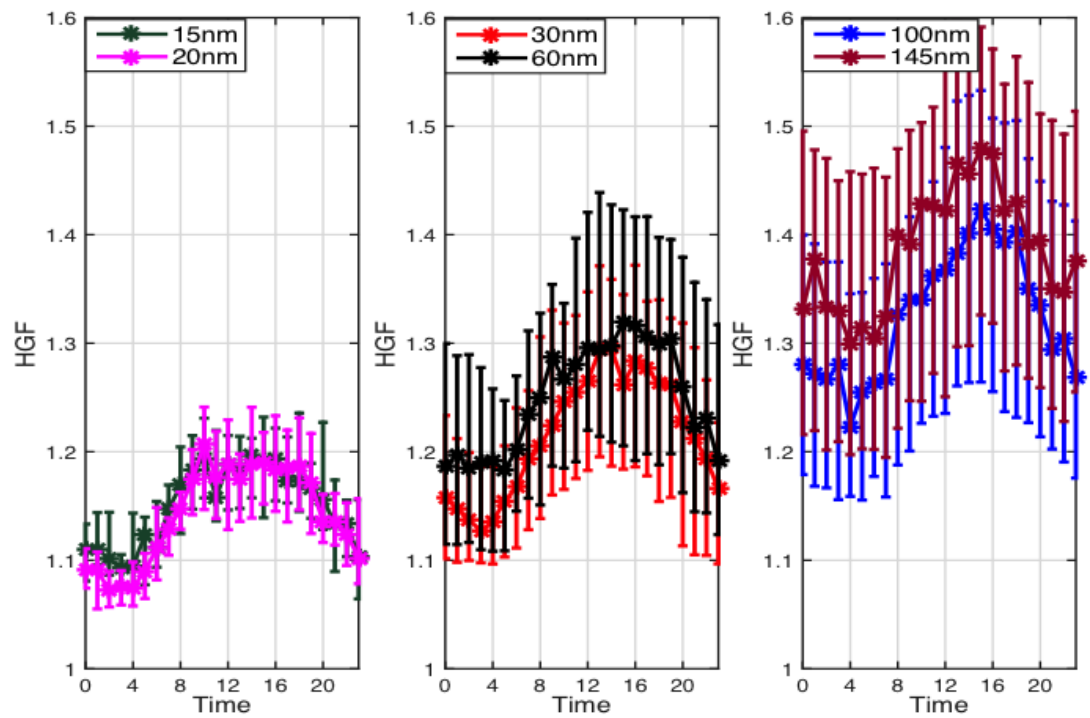

Figure 2. Diurnal variation of hygroscopic growth factor of particles with size of 15, 20, 30, 60, 100 and $145 \mathrm{~nm}$ during the measurement period.
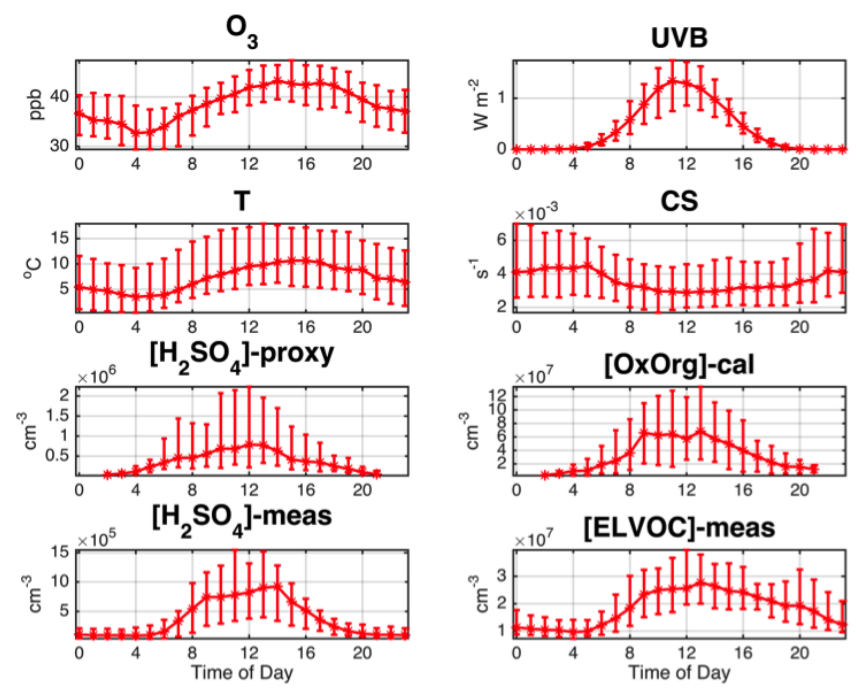

Figure 3. Diurnal variation of $\mathrm{O}_{3}, \mathrm{UV}-\mathrm{B}$, temperature, condensation sink (CS) and calculated sulfuric acid proxy and oxidation organics from monoterpene according to Nieminen et al. (2014) as well as the measured sulfuric acid and ELVOCs concentration in gas phase.

partitioning (directly). More specifically, gas-phase concentration of condensable vapors, such as sulfuric acid that has a high water affinity and ELVOCs that are likely to be less hygroscopic despite their high $\mathrm{O}: \mathrm{C}$ content, reached their maximum around noon (Fig. 3). Since the volume growth of newly formed particles is caused by both sulfuric acid and organic vapor condensation (Riipinen et al., 2012), the increase of the HGF around noon was probably connected to the combination of, or competition between, the condensation of sulfuric acid and ELVOCs. Meanwhile, the ambient
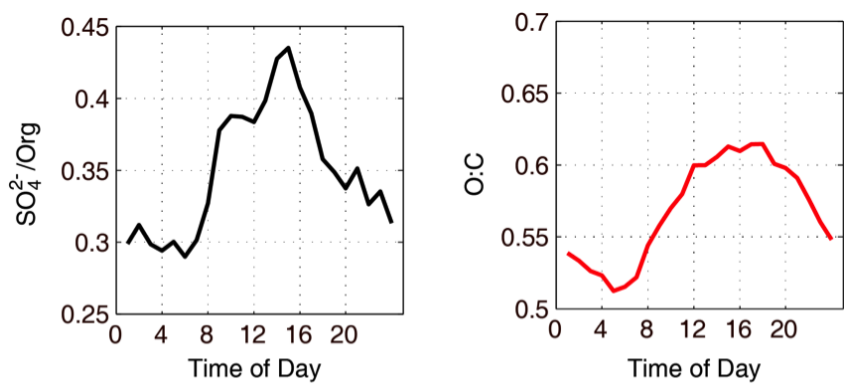

Figure 4. Diurnal variation of $\mathrm{SO}_{4}^{2-} / \mathrm{Org}, \mathrm{O}: \mathrm{C}$ of non-size segregated particles.

temperature was observed to increase from morning until afternoon (Fig. 3), which probably enhanced the evaporation of semi-volatile organics from the particle phase to the gas phase. The loss of these semi-volatile organics, which are less hygroscopic than sulfuric acid or sulfate in particles, may have also contributed to the enhancement in the hygroscopicity from morning until afternoon. Finally, the lifted boundary layer height during daytime, which mixed air masses of different histories, may also have influenced the daytime values of HGF.

A change in the chemical composition of an aerosol particle is the ultimate reason for the diurnal pattern of its HGF. Figure 4 shows the diurnal variation of the ratio of sulfate to organic material $\left(\mathrm{SO}_{4}^{2-} / \mathrm{Org}\right)$ as well as the $\mathrm{O}: \mathrm{C}$ ratio of the organic material in the particles obtained from the HRAMS data. We observe that the $\mathrm{SO}_{4}^{2-} /$ Org ratio started to increase in the late morning, causing the aerosol hygroscopicity to increase. The $\mathrm{O}: \mathrm{C}$ ratio started to increase in the morning and peaked in the afternoon several hours later than 
the ratio $\mathrm{SO}_{4}^{2-}$ / Org did. Since the hygroscopicity of organic particles has been observed to be larger for larger $\mathrm{O}: \mathrm{C}$ ratios (Jimenez et al., 2009; Massoli et al., 2010; Duplissy et al., 2011), the increased $\mathrm{O}: \mathrm{C}$ during the afternoon probably contributed to the increase in the HGF after the maximum levels of condensable sulfuric acid and organic compounds were reached.

Taken together, our results show that the HGF and its diurnal variability at a boreal site is influenced not only by the relative amounts of sulfate and organic material in aerosol particles, but also by the hygroscopic properties of this organic material. The later properties appear to be affected by complicated interactions between the gas-phase chemistry, subsequent gas-particle partitioning of organic compounds and possibly also chemistry (e.g., oxidation) taking place in the particle phase.

\subsection{Closure between the measured and chemically derived HGF}

We compared the HGF of different-sized dry particles measured by the two HTDMA and that derived from dry particle chemical compositions obtained from the HR-AMS measurements based on the ZSR mixing rule. The Kelvin effect was taken into account to the derived HGF to be compared with the measured HGF of the particles of the corresponding size.

The correlation between the chemically derived HGF and the measured HGF increased with increasing particle size, with $R^{2}$ values ranging from 0.15 for nucleation mode particles to 0.62 for the accumulation mode particles (Fig. 5). The HR-AMS measures the bulk chemical composition of particles larger than $80 \mathrm{~nm}$ (Williams et al., 2013). The chemical composition of smaller particles may deviate considerably from that of the bulk, therefore, we focus on accumulation mode particles in the analysis presented below.

\subsubsection{Hygroscopic properties of organics in the accumulation mode}

None of the relations shown in Fig. 5 have a slope close to unity, suggesting that either the assumption of a constant HGF for organic compounds was incorrect or there were systematic errors in either the measurements or ZSR mixing rule, or both. We colored the data points according to the measured $\mathrm{O}: \mathrm{C}$ ratios in Fig. 5. When the $\mathrm{O}: \mathrm{C}$ ratio was higher than about 0.5 , the chemically derived values of HGF tended to be lower than the measured ones, while the opposite was true for the $\mathrm{O}: \mathrm{C}$ ratios lower than about 0.5 . This feature is strongly indicative of $\mathrm{O}: \mathrm{C}$ dependence of the organic material hygroscopic properties in aerosol particles and suggests that the organic material with $\mathrm{O}: \mathrm{C}>0.5$ is more hygroscopic than the average value of 1.17 used above.

Massoli et al. (2010) determined the hygroscopic growth factor of laboratory-generated secondary organic aerosol par- ticles and found it to be a function of the oxidation level $(\mathrm{O}: \mathrm{C})$ of the organic materials. Their best-fit relation resulted in $\mathrm{HGF}_{\text {org }}=(0.58 \pm 0.15) \times(\mathrm{O}: \mathrm{C})+(0.85 \pm 0.08)$ at $90 \% \mathrm{RH}$. We used this same $\mathrm{O}: \mathrm{C}$ dependent growth factor as the input for the HGF of organic material in the accumulation mode particles. The resulting slope between the chemically derived and measured HGF improved substantially, compared with assuming a constant HGF for the organic materials (Fig. 6, upper panel).

We also fitted the hygroscopic growth factor of organic material from our data by letting $\mathrm{HGF}_{\text {org }}$ vary as a function of measured $\mathrm{O}: \mathrm{C}$ assuming a general formula of the form $\mathrm{HGF}_{\text {org }}=a \times(\mathrm{O}: \mathrm{C})+\mathrm{b}$ for particles of each size, such that the sum of all residuals between each pair of measured and derived HGF became minimized (Sjogren et al., 2008). The corresponding results are shown for 100 and $145 \mathrm{~nm}$ particles in the lower panel of Fig. 6. Compared with the fit by Massoli et al. (2010), the slope of the relation between measured and derived HGF improved to a certain extent.

\subsubsection{Organic-inorganic interactions}

Besides the fact that the oxidation level of organic material can affect its hygroscopic properties, the interaction between inorganic and organic material can also influence (either reduce or enhance) the "apparent" HGF of organic matter in mixtures compared with their intrinsic HGF in the pure form (Sjogren et al., 2008; Suda et al., 2014; Hansen et al., 2015, manuscript in preparation). Figure S1 in the Supplement shows an illustration identical to Fig. 6, but colored according to the inorganic volume fraction. It is evident from Fig. S1 that also a parameterization based on the inorganic volume fraction would be able to improve the agreement between the AMS-predicted and measured HGF.

By considering both oxidation level and inorganic fraction, we further attempted to improve the agreement between predicted and measured HGF. We used a three-free parameterization scheme for 100 and $145 \mathrm{~nm}$ particles as the same fitting procedure as discussed above: $\mathrm{HGF}_{\text {org }}=([a \times$ $(\mathrm{O}: \mathrm{C})]+b)\left(1+\left[c \times \varepsilon_{\text {In }}\right]\right)$, where $\varepsilon_{\text {In }}$ stands for the volume fraction of the total inorganics. The results, shown in the lower panel of Fig. 7, improved the slope of the correlation only slightly. This may be because the relation between the "apparent" growth factor of organics and inorganic volume fraction might be non-linear, non-additive and species-dependent, thus making it complicated to unequivocally predict this growth factor (Hansen et al., 2015). Although Fig. S1 suggests a relation between $\varepsilon_{\text {In }}$ and $H_{G F}$ org, we in fact found that there was a clear correlation between the $\mathrm{O}: \mathrm{C}$ ratio of the organics and $\varepsilon_{\mathrm{In}}$ as shown in Fig. S2 in the Supplement. Therefore we cannot unambiguously determine whether the $\mathrm{HGF}_{\text {org }}$ dependence was due to $\mathrm{O}: \mathrm{C}$ or $\varepsilon_{\mathrm{In}}$. For reference, we also fitted the scaling factor from the inorganic volume fraction to the $\mathrm{O}: \mathrm{C}$ dependent equation of Massoli et al. (2010) (upper panels in Fig. 7). However, the resulting 

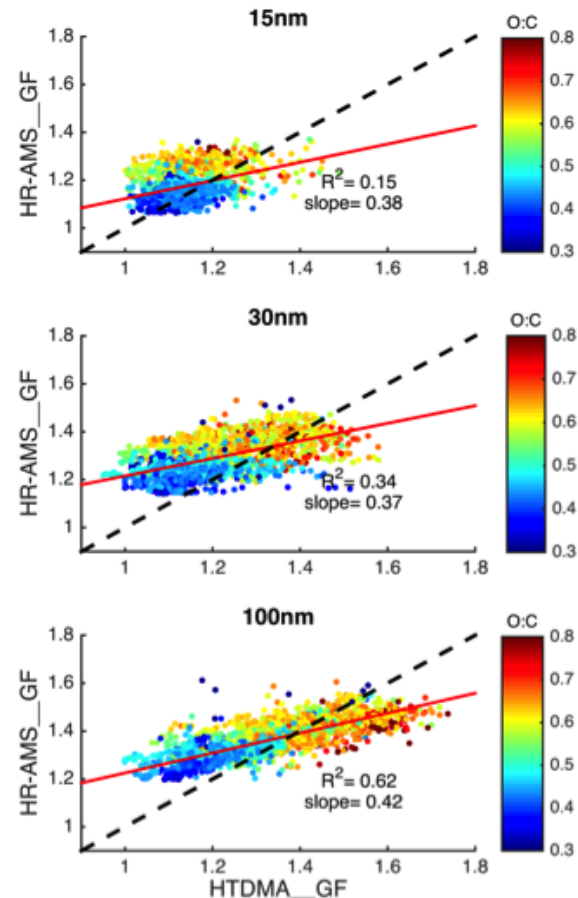
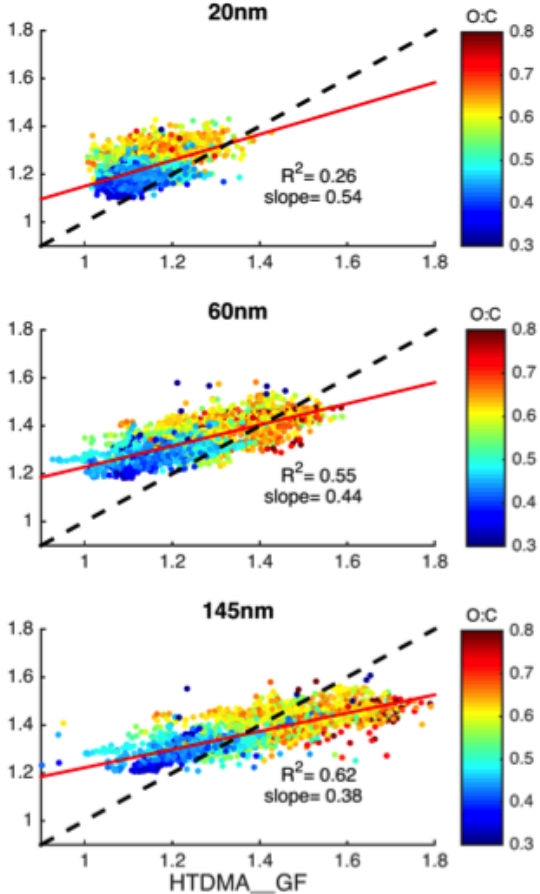

Figure 5. Comparison of HR-AMS-derived HGF with HTDMA-measured HGF of different-sized particles. The dashed lines indicate the $1: 1$ lines.

$100 \mathrm{~nm}$

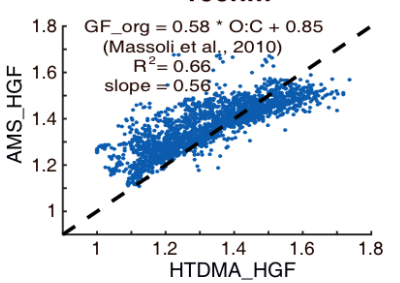

$100 \mathrm{~nm}$

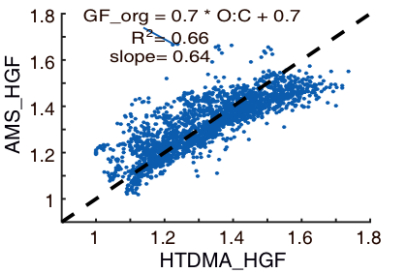

$145 \mathrm{~nm}$

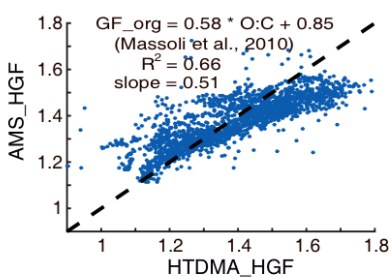

$145 \mathrm{~nm}$

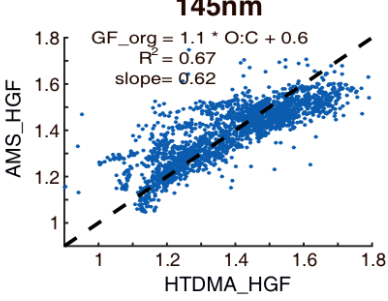

Figure 6. Comparison between AMS-derived HGF with measured HGF when taking into account the influence of oxidation level of the organics on GF, with upper panels using the relation determined by Massoli et al. (2010), and lower panels by fitting the equation $\mathrm{GF}=a \times \mathrm{O}: \mathrm{C}+b$ into our data. The dashed lines indicate the $1: 1$ lines.

slope was not improved, in addition to which we obtained a negative scaling factor $(-0.3)$ from the inorganic fraction to HGF of organics for $100 \mathrm{~nm}$ particles and a positive one for $145 \mathrm{~nm}$ particles.
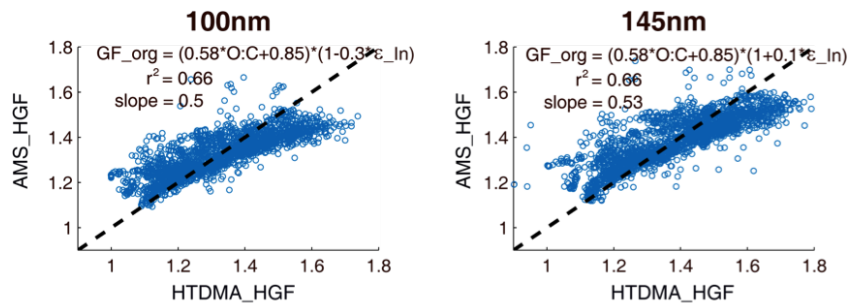

$100 \mathrm{~nm}$

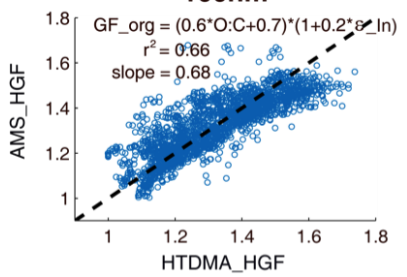

$145 \mathrm{~nm}$

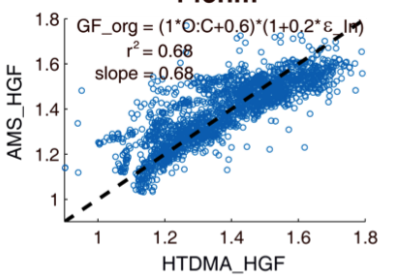

Figure 7. Comparison between AMS-derived HGF with measured HGF when taking into account of both oxidation level and inorganic volume fraction on GF of the organics. The dashed lines indicate the $1: 1$ lines.

Similar to Figs. 6 and 7, new parameterization values were also fitted using the $\mathrm{O}: \mathrm{C}$ ratio obtained from the improvedambient method. However, the new fit only marginally improved the results compared with the slope and $R^{2}$ values using the O:C ratio from "Aiken-Ambient" method (see Sects. 3 and 4). Massoli et al. (2010) also used the "AikenAmbient" method to estimate the $\mathrm{O}: \mathrm{C}$ ratio. For these two 

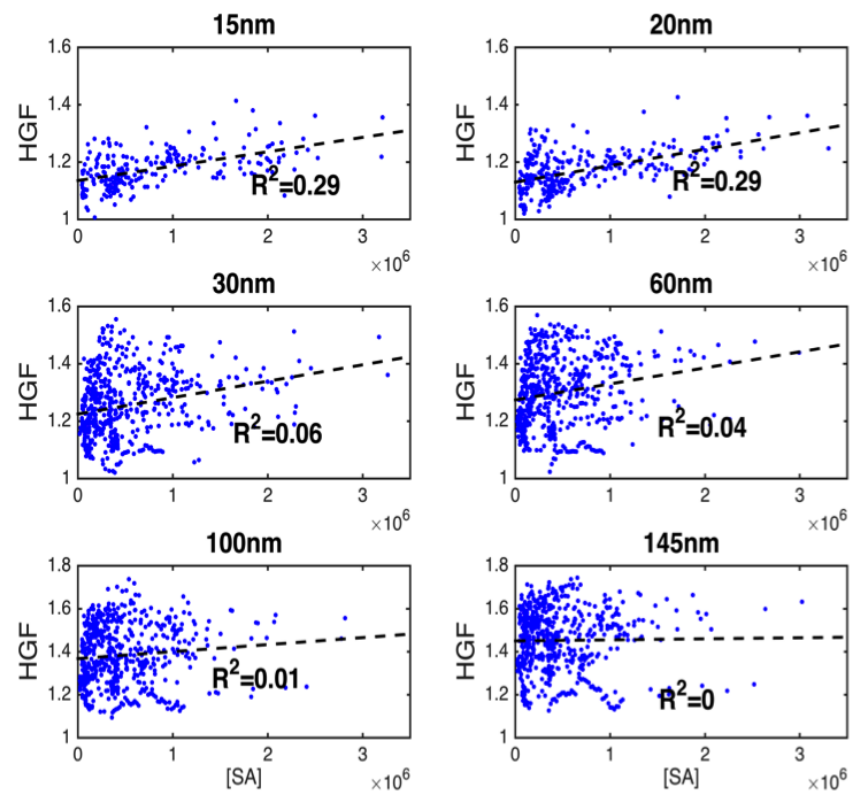

Figure 8. HGF of 15, 20, 30, 60, 100 and $145 \mathrm{~nm}$ particles with sulfuric acid concentration in gas phase during the time of NPF. The dashed lines indicate the linear fit to the full data.

reasons, we present our data using the $\mathrm{O}: \mathrm{C}$ ratio from "Aiken-Ambient" method.

The above findings illustrate that it is highly complex to quantify the influence of the inorganic fraction on the HGF of organic matter. However, one needs to be careful with solute-solute interactions in deriving the additive HGF of an organic-dominated aerosol consisting of a highly complex mixture of some sparingly soluble organics (Hodas et al., 2015; Pajunoja et al., 2015; Virtanen et al., 2010), since the ZSR mixing rule assumes there is no solute-solute interactions. These sparingly soluble organics may undergo further dissolution when there are a certain amount of inorganic compounds exist in the solution (Suda et al., 2014) and thus these organics may appear to have a higher hygroscopic growth factor than in their pure form.

\subsection{Relation between the measured HGF and condensable vapor concentrations}

Since the HGF of aerosol particles showed a clear diel variation, atmospheric photochemistry is very likely to play an important role. Vapor condensation from the gas phase to particles is the most important driver of the growth of atmospheric ultrafine aerosol particles, directly affecting the hygroscopicity of these particles. $\mathrm{H}_{2} \mathrm{SO}_{4}$ and ELVOCs are the major condensing vapor species at our measurement site (Kulmala et al., 2013; Ehn et al., 2014). We selected data during the time periods when particles originated from the regional NPF events in order to study the effect of gas phase composition on nucleation mode particle hygroscopicity.
Figure 8 shows the relation between the HGF and the measured gaseous sulfuric acid concentration for different-sized particles during NPF events, along with a linear fit to these data. We can see that these two quantities correlated moderately for $15 \mathrm{~nm}\left(R^{2}=0.33\right)$ and $20 \mathrm{~nm}\left(R^{2}=0.39\right)$ particles, but not for larger particles. This kind of behavior is expected, since the smaller the particles are, the larger the relative contribution from the immediate vapor condensation they will have and thus the more rapidly their bulk chemical composition responds to changing concentration of condensable vapors.

Besides $\mathrm{H}_{2} \mathrm{SO}_{4}$, organic compounds, especially ELVOCs, are also considered as important condensing vapors to enhance new particle growth (Kulmala et al., 2013; Ehn et al., 2014). Therefore, we also explored the relationship between the measured HGF and ELVOC concentration, but no correlation between these quantities was observed. This is possibly because the hygroscopic properties of organics are expected to vary considerably from compound to compound (Kanakidou et al., 2005). Even though ELVOCs are likely to be more hygroscopic than many other types of organic vapors, their HGF is still expected to be much lower than that of $\mathrm{H}_{2} \mathrm{SO}_{4}$, and therefore the net effect on HGF from ELVOC condensation will be less prominent. However, if we limited our data range to high ozone concentrations (higher than $45 \mathrm{ppb}$ ), the correlation coefficient between HGF and ELVOC concentration became relatively high for $15 \mathrm{~nm}\left(R^{2}=0.46\right), 20 \mathrm{~nm}\left(R^{2}=0.42\right), 30 \mathrm{~nm}\left(R^{2}=0.41\right)$ and $60 \mathrm{~nm}\left(R^{2}=0.36\right)$ particles (Fig. S5). It is hard to speculate over the reason for this behavior, as so little is still known about ELVOCs. However, the level of oxidant concentration and the relative roles of ozone and $\mathrm{OH}$ might be of importance for the ultimate hygroscopicity of ELVOCs. Aimed laboratory experiments should be attempted in the future in order to verify this finding.

\section{Summary and conclusions}

The hygroscopicity of nucleation, Aitken and accumulation mode particles in a boreal environment was studied. Concurrently, the non-size segregated aerosol chemical composition was also determined. The HGF of particles of all sizes showed a clear diel variation, with an increase in the HGF from morning until afternoon as a result of gas-phase chemistry producing condensing vapors and temperaturedependent gas-to-particle partitioning. In addition to these, radiation and/or temperature-driven chemistry taking place in the aerosol phase and entrainment of particles from above the mixed layer during daytime may also have influenced the diel variation of the HGF.

The comparison between the HTDMA-measured and AMS-derived HGF showed a good agreement, especially for larger particles. This comparison also clearly indicated that the HGF of organic material in particles varies with the oxi- 
dation level of this material and possibly also due to its interaction with the inorganic compounds in particles. We found a similar dependence between the HGF of organic compounds and oxidation level as that reported by Massoli et al. (2010). The effect of $\mathrm{O}: \mathrm{C}$ and volume fraction of inorganic species $\left(\varepsilon_{\text {In }}\right)$ on the apparent HGF of organic compounds resulted in the following equation for $100 \mathrm{~nm}$ particles: $\mathrm{HGF}_{\mathrm{org}}=$ $([0.6 \times \mathrm{O}: \mathrm{C}]+0.7) \times\left(1+\left[0.2 \times \varepsilon_{\text {In }}\right]\right)$. However, including the effect of inorganic compounds improved the closure between the measured and chemically derived values of HGF only slightly. More lab work is needed to examine this effect thoroughly.

Compared with accumulation and Aitken mode particles, the hygroscopicity of nucleation mode particles correlated much worse with the AMS-derived HGF, while a better correlation was found with the gas-phase sulfuric acid concentration. No clear dependence was found between the extremely low-volatility organic concentration (ELVOC) and the HGF of particles of any size. However, if we looked at the influence of ELVOC concentration on particle hygroscopicity at $\left[\mathrm{O}_{3}\right]>45 \mathrm{ppb}$, the more ELVOCs in the gas phase, the lower were the HGF of nucleation and Aitken mode particles. More aimed experiments, including chamber studies on ozonolysis and $\mathrm{OH}$-initiated SOA formation, need to be conducted to further understand the oxidant-specific effects on the hygroscopic properties of particle phase organics.

\section{The Supplement related to this article is available online at doi:10.5194/acp-15-11999-2015-supplement.}

Acknowledgements. This work was supported by the CryosphereAtmosphere Interactions in a changing Arctic climate project (CRAICC) (No. 4720479), the Academy of Finland Center of Excellence (no. 1118615, no. 259005), European Research Council (ATM-NUCLE and Grant QAPPA 335478), University of Helsinki funds, and European Commission (ACTRIS, No. 262254) via the project "Pan-European Gas-Aerosols-climate interaction Study" under the Framework Programme 7 (FP7-ENV-2010-265148). Authors also wish to thank the staff at SMEAR II for their assistance throughout the whole intensive campaign.

Edited by: R. Sullivan

\section{References}

Aalto, P., Hämeri, K., Becker, E., Weber, R., Salm, J., Mäkelä, J. M., Hoell, C., O’Dowd C. D., Karlsson, H., Hansson, H.-C., Väkevä, M., Koponen, I. K., Buzorius, G., and Kulmala, M.: Physical characterization of aerosol particles during nucleation events, Tellus, 53B, 344-358, doi:10.1034/j.1600-0889.2001.530403.x, 2001.
Aiken, A. C., DeCarlo, P. F., and Jimenez, J. L.: Elemental Analysis of Organic Species with Electron Ionization HighResolution Mass Spectrometry, Anal. Chem., 79, 8350-8358, doi:10.1021/ac071150w, 2007.

Asmi, E., Frey, A., Virkkula, A., Ehn, M., Manninen, H. E., Timonen, H., Tolonen-Kivimäki, O., Aurela, M., Hillamo, R., and Kulmala, M.: Hygroscopicity and chemical composition of Antarctic sub-micrometre aerosol particles and observations of new particle formation, Atmos. Chem. Phys., 10, 4253-4271, doi:10.5194/acp-10-4253-2010, 2010.

Canagaratna, M. R., Jayne, J. T., Jimenez, J. L., Allan, J. D., Alfarra, M. R., Zhang, Q., Onasch, T. B., Drewnick, F., Coe, H., Middlebrook, A., Delia, A., Williams, L. R., Trimborn, A. M., Northway, M. J., DeCarlo, P. F., Kolb, C. E., Davidovits, P., and Worsnop, D. R.: Chemical and Microphysical Characterization of Ambient Aerosols with the Aerodyne Aerosol Mass Spectrometer, Mass Spectrom. Rev., 26, 185-222, doi:10.1002/mas.20115, 2007.

Canagaratna, M. R., Jimenez, J. L., Kroll, J. H., Chen, Q., Kessler, S. H., Massoli, P., Hildebrandt Ruiz, L., Fortner, E., Williams, L. R., Wilson, K. R., Surratt, J. D., Donahue, N. M., Jayne, J. T., and Worsnop, D. R.: Elemental ratio measurements of organic compounds using aerosol mass spectrometry: characterization, improved calibration, and implications, Atmos. Chem. Phys., 15, 253-272, doi:10.5194/acp-15-253-2015, 2015.

Dal Maso, M., Kulmala, M., Riipinen, I., Wagner, R., Hussein, T., Aalto, P. P. and Lehtinen, K. E. J.: Formation and growth of fresh atmospheric aerosols: eight years of aerosol size distribution data from SMEAR II, Hyytiälä, Finland, Boreal Environ. Res., 10, 323-336, 2005.

DeCarlo, P. F., Kimmel, J. R., Trimborn, A., Northway, M. J., Jayne, J. T., Aiken, A. C., Gonin, M., Fuhrer, K., Horvath, T., Docherty, K., Worsnop, D. R., and Jimenez, J. L.: Field-Deployable, HighResolution, Time-of-Flight Aerosol Mass Spectrometer, Anal. Chem., 78, 8281-8289, doi:10.1021/ac061249n, 2006.

Duplissy, J., DeCarlo, P. F., Dommen, J., Alfarra, M. R., Metzger, A., Barmpadimos, I., Prevot, A. S. H., Weingartner, E., Tritscher, T., Gysel, M., Aiken, A. C., Jimenez, J. L., Canagaratna, M. R., Worsnop, D. R., Collins, D. R., Tomlinson, J., and Baltensperger, U.: Relating hygroscopicity and composition of organic aerosol particulate matter, Atmos. Chem. Phys., 11, 11551165, doi:10.5194/acp-11-1155-2011, 2011.

Ehn, M., Petäjä, T., Aufmhoff, H., Aalto, P., Hämeri, K., Arnold, F., Laaksonen, A., and Kulmala, M.: Hygroscopic properties of ultrafine aerosol particles in the boreal forest: diurnal variation, solubility and the influence of sulfuric acid, Atmos. Chem. Phys., 7, 211-222, doi:10.5194/acp-7-211-2007, 2007.

Ehn, M., Thornton, J. A., Kleist, E., Sipilä, M., Junninen, H., Pullinen, I., Springer, M., Rubach, F., Tillmann, R., Lee, B., LopezHilfiker, F., Andres, S., Acir, I.-H., Rissanen, M., Jokinen, T., Schobesberger, S., Kangasluoma, J., Kontkanen, J., Nieminen, T., Kurten, T., Nielsen , L. B., Jørgensen, S., Kjaergaard, H. G., Canagaratna, M., Dal Maso, M., Berndt, T., Petäjä, T., Wahner, A., Kerminen, V.-M., Kulmala, M., Worsnop, D. R., Wildt, J., and Mentel, T. F.: A large source of low-volatility secondary organic aerosol, Nature., 506, 476-479, doi:10.1038/nature13032, 2014.

Good, N., Topping, D. O., Allan, J. D., Flynn, M., Fuentes, E., Irwin, M., Williams, P. I., Coe, H., and McFiggans, G.: Consis- 
tency between parameterisations of aerosol hygroscopicity and CCN activity during the RHaMBLe discovery cruise, Atmos. Chem. Phys., 10, 3189-3203, doi:10.5194/acp-10-3189-2010, 2010.

Gysel, M., Crosier, J., Topping, D. O., Whitehead, J. D., Bower, K. N., Cubison, M. J., Williams, P. I., Flynn, M. J., McFiggans, G. B., and Coe, H.: Closure study between chemical composition and hygroscopic growth of aerosol particles during TORCH2, Atmos. Chem. Phys., 7, 6131-6144, doi:10.5194/acp-7-61312007, 2007.

Hansen, A. M. K., Hong, J., Raatikainen, T., Kristensen, K., Ylisirniö, A., Virtanen, A., Petäjä, T., Glasius, M., and Prisle, N. L.: Hygroscopic properties and cloud condensation nuclei activation of limonene-derived organosulfates and their mixtures with ammonium sulfate, Atmos. Chem. Phys. Discuss., 15, 1731717365, doi:10.5194/acpd-15-17317-2015, 2015.

Hämeri, K., Väkevä, M., Aalto, P. P., Kulmala, M., Swietlicki, E., Zhou, J., Seidl, W., Becker, E., and O'Dowd, C.: Hygroscopic and $\mathrm{CCN}$ properties of aerosol particles in boreal forests, Tellus, 53B, 359-379, doi:10.1034/j.1600-0889.2001.530404.x, 2001.

Hari, P. and Kulmala, M.: Station for Measuring EcosystemAtmosphere Relations (SMEAR II), Boreal Environ. Res., 10, 315-322, 2005.

Hodas, N., Zuend, A., Mui, W., Flagan, R. C., and Seinfeld, J. H.: Influence of particle-phase state on the hygroscopic behavior of mixed organic-inorganic aerosols, Atmos. Chem. Phys., 15, 5027-5045, doi:10.5194/acp-15-5027-2015, 2015.

Hong, J., Häkkinen, S. A. K., Paramonov, M., Äijälä, M., Hakala, J., Nieminen, T., Mikkilä, J., Prisle, N. L., Kulmala, M., Riipinen, I., Bilde, M., Kerminen, V.-M., and Petäjä, T.: Hygroscopicity, $\mathrm{CCN}$ and volatility properties of submicron atmospheric aerosol in a boreal forest environment during the summer of 2010, Atmos. Chem. Phys., 14, 4733-4748, doi:10.5194/acp-144733-2014, 2014.

IPCC: 2013 Climate change 2013: the physical science basis, Working Group I Contribution to the Fifth Assessment Report of the Intergovernmental Panel on Climate Change, Cambridge University Press, Cambridge, United Kingdom and New York, NY, USA, 2013.

Jimenez, J. L., Canagaratna, M. R., Donahue, N. M., Prevot, A. S. H., Zhang, Q., Kroll, J. H., DeCarlo, P. F., Allan, J. D., Coe, H., Ng, N. L., Aiken, A. C., Docherty, K. S., Ulbrich, I. M., Grieshop, A. P., Robinson, A. L., Duplissy, J., Smith, J. D., Wilson, K. R., Lanz, V. A., Hueglin, C., Sun, Y. L., Tian, J., Laaksonen, A., Raatikainen, T., Rautiainen, J., Vaattovaara, P., Ehn, M., Kulnala, M., Tomlinson, J. M., Collins, D. R., Cubison, M. J., Dunlea, E. J., Huffman, J. A., Onasch, T. B., Alfarra, M. R., Williams, P. I., Bower, K., Kondo, Y., Schneider, J., Drewnick, F., Borrmann, S., Weimer, S., Demerjian, K., Salcedo, D., Cottrell, L., Griffin, R., Takami, A., Miyoshi, T., Hatakeyama, S., Shimono, A., Sun, J. Y., Zhang, Y. M., Dzepina, K., Kimmel, J. R., Sueper, D., Jayne, J. T., Herndon, S. C., Trimborn, A. M., Williams, L. R., Wood, E. C., MIddlebrook, A. M., Kolb, C. E., Baltensperger, U., and Worsnop, D. R.: Evolution of organic aerosols in the atmosphere, Science, 326, 1525, doi:10.1126/science.1180353, 2009.

Jokinen, T., Sipilä, M., Junninen, H., Ehn, M., Lönn, G., Hakala, J., Petäjä, T., Mauldin III, R. L., Kulmala, M., and Worsnop, D. R.: Atmospheric sulphuric acid and neutral cluster measure- ments using CI-APi-TOF, Atmos. Chem. Phys., 12, 4117-4125, doi:10.5194/acp-12-4117-2012, 2012.

Jung, J. and Kawamura, K.: Hygroscopic properties of newly formed ultrafine particles at an urban site surrounded by deciduous forest (Sapporo, northern Japan) during the summer of 2011, Atmos. Chem. Phys., 14, 7519-7531, doi:10.5194/acp-14-75192014, 2014.

Kanakidou, M., Seinfeld, J. H., Pandis, S. N., Barnes, I., Dentener, F. J., Facchini, M. C., Van Dingenen, R., Ervens, B., Nenes, A., Nielsen, C. J., Swietlicki, E., Putaud, J. P., Balkanski, Y., Fuzzi, S., Horth, J., Moortgat, G. K., Winterhalter, R., Myhre, C. E. L., Tsigaridis, K., Vignati, E., Stephanou, E. G., and Wilson, J.: Organic aerosol and global climate modelling: a review, Atmos. Chem. Phys., 5, 1053-1123, doi:10.5194/acp-5-1053-2005, 2005.

Keskinen, H., Virtanen, A., Joutsensaari, J., Tsagkogeorgas, G., Duplissy, J., Schobesberger, S., Gysel, M., Riccobono, F., Slowik, J. G., Bianchi, F., Yli-Juuti, T., Lehtipalo, K., Rondo, L., Breitenlechner, M., Kupc, A., Almeida, J., Amorim, A., Dunne, E. M., Downard, A. J., Ehrhart, S., Franchin, A., Kajos, M. K., Kirkby, J., Kürten, A., Nieminen, T., Makhmutov, V., Mathot, S., Miettinen, P., Onnela, A., Petäjä, T., Praplan, A., Santos, F. D., Schallhart, S., Sipilä, M., Stozhkov, Y., Tomé, A., Vaattovaara, P., Wimmer, D., Prevot, A., Dommen, J., Donahue, N. M., Flagan, R. C., Weingartner, E., Viisanen, Y., Riipinen, I., Hansel, A., Curtius, J., Kulmala, M., Worsnop, D. R., Baltensperger, U., Wex, H., Stratmann, F., and Laaksonen, A.: Evolution of particle composition in CLOUD nucleation experiments, Atmos. Chem. Phys., 13, 5587-5600, doi:10.5194/acp-13-5587-2013, 2013.

Kulmala, M., Kontkanen, J., Junninen, H., Lehtipalo, K., Manninen, H. E., Nieminen, T., Petäjä, T., Sipilä, M., Schobesberger, S., Rantala, P., Franchin, A., Jokinen, T., Järvinen, E., Äijälä, M., Kangasluoma, J., Hakala, J., Aalto, P. P., Paasonen, P., Mikkilä, J., Vanhanen, J., Aalto, J., Hakola, H., Makkonen, U., Ruuskanen, T., Mauldin III, R. L., Duplissy, J., Vehkamäki, H., Bäck, J., Kortelainen, A., Riipinen, I., Kurtén, T., Johnston, M. V., Smith, J. N., Ehn, M., Mentel, T. F., Lehtinen, K. E. J., Laaksonen, A., Kerminen, V.-M., and Worsnop, D. R.: Direct observation of atmospheric aerosol nucleation, Science, 339, 943-946, doi:10.1126/science.1227385, 2013.

Kürten, A., Rondo, L., Ehrhart, S., and Curtius, J.: Calibration of a Chemical Ionization Mass Spectrometer for the Measurement of Gaseous Sulfuric Acid, J. Phys. Chem. A., 116, 6375-6386, doi:10.1021/jp212123n, 2012.

Massoli, P., Lambe, A. T., Ahern, A. T., Williams, L. R., Ehn, M., Mikkilä, J., Canagaratna, M. R., Brune, W. H., Onasch, T. B., Jayne, J. T., Petäjä, T., Kulmala, M., Laaksonen, A., Kolb, C. E., Davidovits, P., and Worsnop, D. R.: Relationship between aerosol oxidation level and hygroscopic properties of laboratory generated secondary organic aerosol (SOA) particles, Geophys. Res. Lett., 37, L24801, doi:10.1029/2010GL045258, 2010.

Meyer, N. K., Duplissy, J., Gysel, M., Metzger, A., Dommen, J., Weingartner, E., Alfarra, M. R., Prevot, A. S. H., Fletcher, C., Good, N., McFiggans, G., Jonsson, A. M., Hallquist, M., Baltensperger, U., and Ristovski, Z. D.: Analysis of the hygroscopic and volatile properties of ammonium sulphate seeded and unseeded SOA particles, Atmos. Chem. Phys., 9, 721-732, doi:10.5194/acp-9-721-2009, 2009. 
Nieminen, T., Asmi, A., Dal Maso, M., P. Aalto, P., Keronen, P., Petäjä, T., Kulmala, M., and Kerminen, V.-M.: Trends in atmospheric new-particle formation: 16 years of observations in a boreal-forest environment, Boreal Environ. Res., 19 (suppl. B), 191-214, 2014.

Paasonen, P., Nieminen, T., Asmi, E., Manninen, H. E., Petäjä, T., Plass-Dülmer, C., Flentje, H., Birmili, W., Wiedensohler, A., Hõrrak, U., Metzger, A., Hamed, A., Laaksonen, A., Facchini, M. C., Kerminen, V.-M., and Kulmala, M.: On the roles of sulphuric acid and low-volatility organic vapours in the initial steps of atmospheric new particle formation, Atmos. Chem. Phys., 10, 11223-11242, doi:10.5194/acp-10-11223-2010, 2010.

Pajunoja, A., Lambe, A. T., Hakala, J., Rastak, N., Cummings, M. J., Brogan, J. F., Hao, L., Paramonov, M., Hong, J., Prisle, N. L., Malila, J., Romakkaniemi, S., Lehtinen, K. E. J., Laaksonen, A., Kulmala, M., Massoli, P., Onasch, T. B., Donahue, N. M., Riipinen, I., Davidovits, P., Worsnop, D. R., Petäjä, T., and Virtanen, A.: Adsorptive uptake of water by semisolid secondary organic aerosols in the atmosphere, Geosci. Res. Lett., 42, doi:10.1002/2015GL063142, 2015.

Raatikainen, T., Vaattovaara, P., Tiitta, P., Miettinen, P., Rautiainen, J., Ehn, M., Kulmala, M., Laaksonen, A., and Worsnop, D. R.: Physicochemical properties and origin of organic groups detected in boreal forest using an aerosol mass spectrometer, Atmos. Chem. Phys., 10, 2063-2077, doi:10.5194/acp-10-20632010, 2010.

Regayre, L. A., Pringle, K. J., Booth, B. B. B., Lee, L. A., Mann, G. W., Browse, J., Woodhouse, M. T., Rap, A., Reddington, C. L., and Carslaw, K. S.: Uncertainty in the magnitude of aerosolcould radiative forcing over recent decades, Geophys. Res. Lett., 41, 9040-9049, doi:10.1002/2014GL062029, 2014.

Riipinen, I., Yli-Juuti, T., Pierce, J. R., Petäjä, T., Worsnop, D. R., Kulmala, M., and Donahue, N. M.: The contribution of organics to atmospheric nanoparticle growth, Nat. Geosci., 5, 453-458, doi:10.1038/ngeo1499, 2012.

Ristovski, Z. D., Suni, T., Kulmala, M., Boy, M., Meyer, N. K., Duplissy, J., Turnipseed, A., Morawska, L., and Baltensperger, U.: The role of sulphates and organic vapours in growth of newly formed particles in a eucalypt forest, Atmos. Chem. Phys., 10, 2919-2926, doi:10.5194/acp-10-2919-2010, 2010.

Rosenfeld, D., Sherwood, S., Wood, R., and Donner, L.: Climate effects of aerosol-cloud interactions, science., 343, p. 379, doi:10.1126/science.1247490, 2014

Saathoff, H., Naumann, K. H., Schnaiter, M., Schock, W., Mohler, O., Schurath, U., Weingartner, E., Gysel, M., and Baltensperger, U.: Coating of soot and $\left(\mathrm{NH}_{4}\right)_{2} \mathrm{SO}_{4}$ particles by ozonolysis products of alpha-pinene, J. Aerosol Sci., 34, 1297-1321, doi:10.1016/S0021-8502(03)00364-1, 2003.

Sjogren, S., Gysel, M., Weingartner, E., Alfarra, M. R., Duplissy, J., Cozic, J., Crosier, J., Coe, H., and Baltensperger, U.: Hygroscopicity of the submicrometer aerosol at the high-alpine site Jungfraujoch, $3580 \mathrm{~m}$ a.s.1., Switzerland, Atmos. Chem. Phys., 8, 5715-5729, doi:10.5194/acp-8-5715-2008, 2008.

Stevens, B. and Feingold, G., Untangling aerosol effects on clouds and precipitation in a buffered system, Nature, 461, 607-613, doi:10.1038/nature08281, 2009.
Stokes, R. H. and Robinson, R. A.: Interactions in aqueous nonelectrolyte solutions. I. Solute-solvent equilibria, J. Phys. Chem., 70, 2126-2130, doi:10.1021/j100879a010, 1966.

Suda, S. R., Petters, M. D., Yeh, G. K., Strollo, C., Matsunaga, A., Faulhaber, A., Ziemann, P. J., Prenni, A. J., Carrico, C. M., Sullivan, R. C., and Kreidenweis, S. M.: Influence of functional groups on organic aerosol cloud condensation nucleus activity, Environ. Sci. Technol., 48, 10182-10190, doi:10.1021/es502147y, 2014.

Swietlicki, E., Hansson, H. C., Hämeri, K., Svenningsson, B., Massling, A., McFiggans, G., McMurry, P. H., Petäjä, T., Tunved, P., Gysel, M., Topping, D., Weingartner, E., Baltensperger, U., Rissler, J., Wiedensohler, A., and Kulmala, M.: Hygroscopic properties of submicrometer atmospheric aerosol particles measured with H-TDMA instruments in various environments - a review, Tellus., 60B, 432-469, doi:10.1111/j.16000889.2008.00350.x, 2008.

Varutbangkul, V., Brechtel, F. J., Bahreini, R., Ng, N. L., Keywood, M. D., Kroll, J. H., Flagan, R. C., Seinfeld, J. H., Lee, A., and Goldstein, A. H.: Hygroscopicity of secondary organic aerosols formed by oxidation of cycloalkenes, monoterpenes, sesquiterpenes, and related compounds, Atmos. Chem. Phys., 6, 23672388, doi:10.5194/acp-6-2367-2006, 2006.

Virtanen, A., Joutsensaari, J., Koop, T., Kannosto, J., Yli-Pirilä, P., Leskinen, J., Mäkelä, J. M., Holopainen, J. K., Pöschl, U., Kulmala, M., Worsnop, D. R., and Laaksonen, A.: An amorphous solid state of biogenic secondary organic aerosol particles, Nature, 467, 824-827, doi:10.1038/nature09455, 2010.

Winklmayr, W., Reischl, G. P., Lindner, A. O., and Berner, A.: A new electromobility spectrometer for the measurement of aerosol size distributions in the size range from 1 to $1000 \mathrm{~nm}$, J. Aerosol Sci., 22, 289-296, doi:10.1016/S0021-8502(05)80007-2, 1991.

Williams, L. R., Gonzalez, L. A., Peck, J., Trimborn, D., McInnis, J., Farrar, M. R., Moore, K. D., Jayne, J. T., Robinson, W. A., Lewis, D. K., Onasch, T. B., Canagaratna, M. R., Trimborn, A., Timko, M. T., Magoon, G., Deng, R., Tang, D., de la Rosa Blanco, E., Prévôt, A. S. H., Smith, K. A., and Worsnop, D. R.: Characterization of an aerodynamic lens for transmitting particles greater than 1 micrometer in diameter into the Aerodyne aerosol mass spectrometer, Atmos. Meas. Tech., 6, 3271-3280, doi:10.5194/amt-6-3271-2013, 2013.

Wu, Z., Birmili, W., Poulain, L., Wang, Z., Merkel, M., Fahlbusch, B., van Pinxteren, D., Herrmann, H., and Wiedensohler, A.: Particle hygroscopicity during atmospheric new particle formation events: implications for the chemical species contributing to particle growth, Atmos. Chem. Phys., 13, 6637-6646, doi:10.5194/acp-13-6637-2013, 2013.

Zdanovskii, A.: New methods for calculating solubilities of electrolytes in multicomponent systems, Zhur. Fiz. Khim., 22, 14751485, 1948. 